\title{
Biological aspects of Tetranychus marianae McGregor (Acari, Tetranychidae) reared on yellow passion fruit (Passiflora edulis Sims f. flavicarpa Deg.) leaves
}

\author{
Aloyséia C. da S. Noronha
}

Embrapa Mandioca e Fruticultura Tropical. Caixa Postal 007, 44380-000 Cruz das Almas, Bahia, Brasil. E-mail: aloyseia@cnpmf.embrapa.br

\begin{abstract}
The passion fruit plant is a host for several different phytophagous mites, mainly those belonging to the Tarsonemidae, Tenuipalpidae and Tetranychidae families. Among the Tetranychidae species are Tetranychus mexicanus (McGregor, 1950) and Tetranychus desertorum Banks, 1900. The occurrence of Tetranychus marianae McGregor, 1950 was detected on yellow passion fruit Passiflora edulis Sims f. flavicarpa Degener plants under field and greenhouse conditions at the headquarters of Embrapa Cassava \& Fruits Tropical Research in Cruz das Almas County, State of Bahia, Northeast Brazil. Prior records of T. marianae on the passion fruit crop in Brazil as well as the biological aspects of this species are unknown. The study on the biology of $T$. marianae on $P$. edulis f. flavicarpa was carried out under controlled environmental condition of $25 \pm 1{ }^{\circ} \mathrm{C}$ temperature, $80 \pm 10 \%$ RH and 12 hours photophase. The egg to adult time span lasted $10.73 \pm 0.18$ days, with a $92 \%$ survival figure. The sexual ratio was $81 \%$ females. The mean female longevity was 24.53 days and the daily mean oviposition was 3.69 eggs/female. The intrinsic rate of increase $\left(r_{m}\right)$ was 0.172 ; the finite rate of increase $(\lambda)$ was 1.187 individuals / female/day; the mean time span of one generation ( $T$ ) was 22.81 days; and the net rate of reproduction ( $R_{o}$ ) was 50.14 .

KEY WORDS. Fertility; life table; mite; Passiflora sp.
\end{abstract}

RESUMO. Aspectos biológicos de Tetranychus marianae McGregor (Acari, Tetranychidae) sobre folhas de maracujazeiro (Passiflora edulis Sims. f. flavicarpa Deg.). A cultura do maracujazeiro é hospedeira de ácaros fitófagos pertencentes principalmente às famílias Tarsonemidae, Tenuipalpidae e Tetranychidae. Dentre as espécies de tetraniquídeos encontram-se Tetranychus mexicanus (McGregor, 1950) e Tetranychus desertorum Banks, 1900. A ocorrência de Tetranychus marianae McGregor, 1950 foi verificada em plantas de maracujá amarelo Passiflora edulis Sims. f. flavicarpa Degener, em condições de campo e casa de vegetação, na sede da Embrapa Mandioca e Fruticultura Tropical, em Cruz das Almas, BA. O registro de T. marianae na cultura do maracujá no Brasil, assim como os aspectos biológicos dessa espécie são desconhecidos. $O$ estudo da biologia de $T$. marianae em $P$. edulis f. falvicarpa foi conduzido a $25 \pm 1^{\circ} \mathrm{C}, 80 \pm 10 \%$ de UR e 12 horas de fotofase. O período de ovo a adulto durou 10,73 $\pm 0,18$ dias, com sobrevivência de $92 \%$. A razão sexual foi $81 \%$ de fêmeas. A longevidade média das fêmeas foi de 24,53 dias e a oviposição média diária de 3,69 ovos/fêmea. A razão intrínseca de aumento $\left(r_{m}\right)$ foi de 0,172, a razão finita de aumento $(\lambda)$ de 1,187 indivíduos por fêmea por dia, o tempo médio de uma geração (T) de 22,81 dias e a taxa líquida de reprodução $\left(R_{0}\right)$ de 50,14 .

PALAVRAS-CHAVES. Ácaro; fertilidade; tabela de vida; Passiflora sp.

Several species of insects and pest-mites, which may cause production impairment, are associated to passion fruit crop. Among the harmful agents, some species of phytophagous mites belonging to Brevipalpus phoenicis (Geijskes, 1939) (Tenuipalpidae); Polyphagotarsonemus latus (Banks, 1904) (Tarsonemidae); and Tetranychus mexicanus (McGregor, 1950) and Tetranychus desertorum (Banks, 1900) (Tetranychidae) are prominent.

The damage caused by $B$. phoenicis on passion fruit plant are very severe when associated to the viral disease known as green spot, as a consequence of the significant defoliation, which can shortening the profitable life of the plants or even prevent production (S̃̃o José et al. 2000, NoronHA et al. 2004). The attack of $P$. latus on new shoots causes malformation of nervures and leaves, which become intensely dark green and do not develop completely and consequently fall (FLECHTMANN 1989). T. mexicanus and T. desertorum form colonies on the leaves, which show whitish or silvery spots that subsequently become dry (Flechtmann 1989).

The occurrence of Tetranychus marianae McGregor, 1950 (Tetranychidae) was detected on yellow passion fruit Passiflora

Revista Brasileira de Zoologia 23 (2): 404-407, junho 2006 
edulis Sims f. flavicarpa Degener plants under field and greenhouse conditions at the headquarters of the Embrapa Cassava \& Fruits Tropical Research Center, in Cruz das Almas County, State of Bahia, Northeast Brazil (1240'39"S, 3906'23"W). Colonies of this species are found on the abaxial surface of leaves with the presence of scarce or abundant web formation (Оснод et al. 1994). The adult females are red in color (JEppson et al. 1975, Flechtmann 1989). This species has also been described as a pest on cotton as well as occurring on other crops such as castor bean, passion fruit, papaya and cassava, besides other herbaceous plants (Jeppson et al. 1975, Moraes et al. 1987, Bonato \& GutierRez 1999). It is distributed in the North America and regions of the Pacific. In Brazil, this species has been already reported in the States of Bahia, Ceará, Pernambuco, and São Paulo on Thunbergia sp. (Acanthaceae), Chenopodium ambrosioides Linnaeus (Chenopodiaceae), Ipomea batatas (Linnaeus) Lamark (Convolvulaceae), Sechium edule (Jacquin) Swartz (Cucurbitaceae), Ricinus communis Linnaeus (Euphorbiaceae), Glycine max (Linnaeus) Merrill (Fabaceae), Hibiscus esculentus Linnaeus (Malvaceae), Psidium guajava Linnaeus (Myrtaceae), Morus sp. (Moraceae), Piper sp. (Piperaceae), Capsicum anuum Linnaeus, Lycopersicon esculentum Miller, Solanum gilo Raddi and Solanum melongena Linnaeus (Solanaceae) (CAVALCANTE et al. 1977, MoraEs \& Flechtmann 1981, Moraes et al. 1987).

In the State of Bahia FlechtMAnn \& AbReu (1973) collected specimens of T. marianae on mulberry Morus sp., chayote $S$. edule, castor bean R. communis, sweet potato I. batatas, okra Abelmoschus esculentus (Linnaeus) Moench (Malvaceae), and Thunbergia sp. plants in the regions of Itabuna, Salvador and Uruçuca counties. Bolland et al. (1998) reported the occurrence of T. marianae on Passiflora biflora Lamark, P. edulis, P. foetida Linnaeus and Passiflora sp. (Passifloraceae).

BonAto \& Gutierrez (1999) studied the fecundity and longevity of inseminated and non-inseminated $T$. marianae females. These authors found that the fecundity was approximately twofold higher in inseminated females and that the mean longevity was reached more rapidly in inseminated females as compared to non-inseminated ones.

Little is know regarding the particularities on the biology of this species (Jeppson et al. 1975, Bonato \& Gutierrez 1999). Therefore, the study on the biology of $T$. marianae on yellow passion fruit was carried out under laboratory conditions.

\section{MATERIAL AND METHODS}

The study was conducted at the Laboratory of Entomology of Embrapa Cassava \& Fruits Tropical Research Center under controlled environmental conditions of $25 \pm 1^{\circ} \mathrm{C}$ temperature, $80 \pm 10 \%$ Relative Humidity and 12 hours photophase.

A colony of $T$. marianae was established on yellow passion fruit leaves starting with mites collected in the field. The rearing was carried out in $14 \mathrm{~cm}$ diameter $\mathrm{x} 2 \mathrm{~cm}$ deep Petri dishes containing a passion fruit leaf with its adaxial surface in contact with a layer of nylon foam moistened with distilled water, which was then surrounded by an also moistened with distilled water layer of cotton.

To obtain eggs, $50 \mathrm{~T}$. marianae females were taken from the stock colony and individually maintained on $2.5 \mathrm{~cm}$ diameter passion fruit leaf disks for oviposition. The disks were maintained on top of distilled water moistened nylon foam sections individually placed into $14 \mathrm{~cm} \mathrm{x} 2 \mathrm{~cm}$ Petri dishes (Noronha et al. 1995). After $24 \mathrm{~h}$, the females were removed and a single egg was maintained per leaf disk. Daily observations were carried out for stage changes verification. The leaf disks were replaced every two days, except when the mites were in the quiescent stage. After emergence of adults, one male from the stock colony was for each female. In case of death, the male was replaced by another from the same stock colony. The adults were transferred to fresh leaf disks at two day interval and the progenies were reared until the adult phase for sexual rate determination.

The parameters evaluated were: incubation period, time span of the development stages, viability, sexual rate, fecundity, and longevity. Data obtained were used to build the fertility life table (BIRCH 1948).

\section{RESULTS AND DISCUSSION}

The mean incubation period for the eggs was 4.63 days and the mean time span from egg to adult was 10.73 days with 92\% survival (Tab. I).

Table I. Mean time span and viability of developmental stages of Tetranychus marianae on yellow passion fruit Passiflora edulis Sims f. flavicarpa Deg.

\begin{tabular}{lcc}
\hline \multicolumn{1}{c}{ Stages } & Time span (days) & Viability (\%) \\
\hline Egg & $4.63 \pm 0.01$ & 100 \\
Larva & $1.37 \pm 0.08$ & 98 \\
Protochrysalide & $0.95 \pm 0.08$ & 96 \\
Protonymph & $0.96 \pm 0.08$ & 96 \\
Deutochrysalide & $0.59 \pm 0.05$ & 96 \\
Deutonymph & $1.31 \pm 0.07$ & 92 \\
Teliochrysalide & $0.86 \pm 0.04$ & 92 \\
Egg to Adult & $10.73 \pm 0.18$ & - \\
\hline
\end{tabular}

SEM: standard error.

The mean oviposition period was 19.85 days (Tab. II). The daily mean oviposition was 3.69 eggs/female and the interval of variation in the total number of eggs/female was from 3 to 170 . The sexual proportion was $81 \%$ females.

The maximum daily oviposition rate was reached at the $14^{\text {th }}$ day after emergence of females and the maximum rate of population increase occurred between the first and fifth oviposition days (Fig. 1).

In relation to the parameters obtained by the fertility life table (Tab. III), the net rate of reproduction $\left(\mathrm{R}_{\mathrm{o}}\right.$ ) was 50.14 
Table II. Mean time span of the phases of the adult stage and daily mean oviposition of Tetranychus marianae on yellow passion fruit Passiflora edulis Sims f. flavicarpa Deg.

\begin{tabular}{lc}
\hline \multicolumn{1}{c}{ Phases } & Time span (days) \\
\hline Preoviposition & $1.10 \pm 0.44$ \\
Oviposition & $19.85 \pm 10.77$ \\
Longevity & \\
Female & $24.53 \pm 11.12$ \\
Male & $8.14 \pm 1.70$ \\
\hline \multicolumn{1}{c}{ Oviposition } & Number of eggs \\
\hline Eggs/female & $75.46 \pm 6.22$ \\
Eggs/female/day & $3.69 \pm 0.15$ \\
\hline
\end{tabular}

( SEM: standard error of the mean.

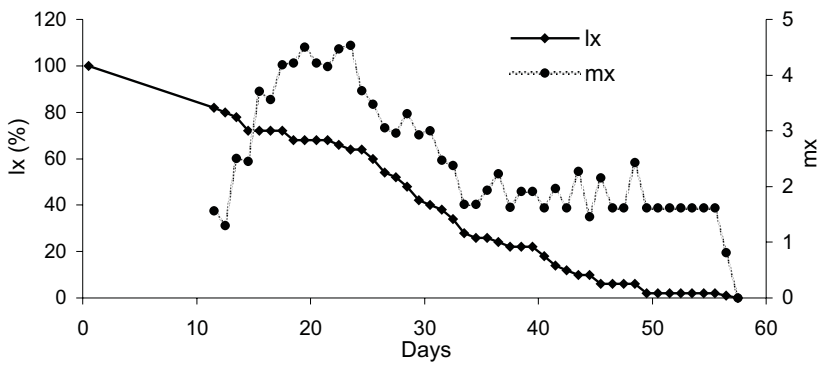

Figure 1. Survival (Ix) and specific fertility $(\mathrm{mx})$ of Tetranychus marianae on yellow passion fruit Passiflora edulis Sims f. flavicarpa Deg.

indicating that the mite has a capacity of increase 50.14 times each generation, with a mean time span (T) of 22.81 days. The intrinsic rate of increase $\left(\mathrm{r}_{\mathrm{m}}\right)$ was 0.172 and the finite rate of increase $(\lambda)$ was 1.187 individuals/female/day.

Results obtained for development of $T$. marianae are within the variation pattern for Tetranychidae mites. CAREY \& Bradley (1982) found periods of egg incubation for three Tetranychidae species varying from 4.41 to 4.95 days at $23.8^{\circ} \mathrm{C}$. Crooker (1985) reported that the developmental period from egg to adult in the Tetranychidae may vary from six to 10 days or more depending on the species, temperature, humidity, host plant and other factors. The author also reviewed a series of studies on the development of several Tetranychidae species. MoraEs \& McMurtry (1987) reported a period of 13.1 days for Tetranychus evansi Baker \& Pritchard, 1960, on Solanum douglasii Dunal (Solanaceae), at $25^{\circ} \mathrm{C}$. Noronha et al. (1995) obtained periods from eggs to adults varying from 12.6 to 13.1 days for Mononychellus tanajoa (Bondar, 1938) on four varieties of cassava.

The longevity of T. marianae females found in this study was close to that of 30 days reported by Bonato \& GuTierrez (1999) for females reared at $25^{\circ} \mathrm{C}$ temperature and $80 \pm 10 \% \mathrm{RH}$ on common beans Phaseolus vulgaris Linnaeus (Fabaceae) leaves, and maintained with the males until the third day after emergence. Moraes \& McMurtry (1987) obtained figures of 35.8 days
Table III. Fertility life table of Tetranychus marianae on yellow passion fruit Passiflora edulis Sims f. flavicarpa Deg.

\begin{tabular}{|c|c|c|c|c|}
\hline$x$ (days) & $m x$ & IX & $m x . I x$ & $m x . I x . x$ \\
\hline 0.5 & - & 1.00 & - & - \\
\hline 10.5 & - & 0.92 & - & - \\
\hline 11.5 & 1.56 & 0.82 & 1.28 & 14.72 \\
\hline 12.5 & 1.30 & 0.80 & 1.04 & 13.00 \\
\hline 13.5 & 2.51 & 0.78 & 1.96 & 26.46 \\
\hline 14.5 & 2.45 & 0.72 & 1.76 & 25.52 \\
\hline 15.5 & 3.71 & 0.72 & 2.67 & 41.39 \\
\hline 16.5 & 3.56 & 0.72 & 2.56 & 42.24 \\
\hline 17.5 & 4.19 & 0.72 & 3.02 & 52.85 \\
\hline 18.5 & 4.22 & 0.68 & 2.87 & 53.10 \\
\hline 19.5 & 4.50 & 0.68 & 3.06 & 53.55 \\
\hline 20.5 & 4.22 & 0.68 & 2.87 & 58.84 \\
\hline 21.5 & 4.15 & 0.68 & 2.82 & 60.63 \\
\hline 22.5 & 4.47 & 0.66 & 2.95 & 66.38 \\
\hline 23.5 & 4.53 & 0.64 & 2.90 & 68.15 \\
\hline 24.5 & 3.72 & 0.64 & 2.38 & 58.31 \\
\hline 25.5 & 3.48 & 0.60 & 2.09 & 53.30 \\
\hline 26.5 & 3.06 & 0.54 & 1.65 & 43.73 \\
\hline 27.5 & 2.96 & 0.52 & 1.54 & 42.35 \\
\hline 28.5 & 3.31 & 0.48 & 1.59 & 45.32 \\
\hline 29.5 & 2.93 & 0.42 & 1.23 & 36.29 \\
\hline 30.5 & 3.00 & 0.40 & 1.20 & 36.60 \\
\hline 31.5 & 2.47 & 0.38 & 0.94 & 29.61 \\
\hline 32.5 & 2.38 & 0.34 & 0.81 & 26.33 \\
\hline 33.5 & 1.68 & 0.28 & 0.47 & 15.75 \\
\hline 34.5 & 1.68 & 0.26 & 0.44 & 15.18 \\
\hline 35.5 & 1.93 & 0.26 & 0.50 & 17.75 \\
\hline 36.5 & 2.23 & 0.24 & 0.54 & 19.71 \\
\hline 37.5 & 1.62 & 0.22 & 0.36 & 13.50 \\
\hline 38.5 & 1.91 & 0.22 & 0.42 & 16.17 \\
\hline 39.5 & 1.91 & 0.22 & 0.42 & 16.59 \\
\hline 40.5 & 1.62 & 0.18 & 0.29 & 11.75 \\
\hline 41.5 & 1.97 & 0.14 & 0.28 & 11.62 \\
\hline 42.5 & 1.62 & 0.12 & 0.19 & 8.08 \\
\hline 43.5 & 2.27 & 0.10 & 0.23 & 10.01 \\
\hline 44.5 & 1.46 & 0.10 & 0.15 & 6.68 \\
\hline 45.5 & 2.16 & 0.06 & 0.13 & 5.92 \\
\hline 46.5 & 1.62 & 0.06 & 0.10 & 4.65 \\
\hline 47.5 & 1.62 & 0.06 & 0.10 & 4.75 \\
\hline 48.5 & 2.43 & 0.04 & 0.10 & 4.85 \\
\hline 49.5 & 1.62 & 0.02 & 0.03 & 1.49 \\
\hline 50.5 & 1.62 & 0.02 & 0.03 & 1.52 \\
\hline 51.5 & 1.62 & 0.02 & 0.03 & 1.55 \\
\hline 52.5 & 1.62 & 0.02 & 0.03 & 1.58 \\
\hline 53.5 & 1.62 & 0.02 & 0.03 & 1.61 \\
\hline 54.5 & 1.62 & 0.02 & 0.03 & 1.64 \\
\hline 55.5 & 1.62 & 0.02 & 0.03 & 1.67 \\
\hline 56.5 & 0.81 & 0.02 & 0.02 & 1.13 \\
\hline 57.5 & 0.00 & 0.02 & 0.00 & 0.00 \\
\hline 58.5 & 0.00 & 0.00 & 0.00 & 0.00 \\
\hline$\Sigma$ & & 114.56 & 50.14 & $1,143.83$ \\
\hline
\end{tabular}


and 16.7 days for $T$. evansi females, reared at $25^{\circ} \mathrm{C}$ and $30^{\circ} \mathrm{C}$, respectively.

The accumulated mean fecundity of 141.91 eggs observed in this study was lower than that of 249.50 eggs observed by Bonato \& Gutierrez (1999).

The identified specimens of T. marianae are deposited at the collection of references of mites of the Museu de Ciências Naturais do Centro Universitário UNIVATES (Museum of Natural Sciences of the UNIVATES University Center), Lajeado, State of Rio Grande do Sul, Brazil.

\section{ACKNOWLEDGEMENT}

The author would like to thank Dr. Noeli Juarez Ferla from Centro Universitário UNIVATES, Lajeado, State of Rio Grande do Sul, for the identification of the mite species.

\section{REFERENCES}

BIRCH, L.C. 1948. The instrinsec rate of natural increase of an insect population. Journal of Animal Ecology, Cambridge, 17: 15-26.

Bolland, H.R.; J. Gutierrez \& C.H.W. Flechtmann. 1998. World catalogue of the spider mite family (Acari: Tetranychidae). Lieden, Brill, 392p.

Bonato, O. \& J. Gutierrez. 1999. Effect of mating status on the fecundity and longevity of four spider mite species (Acari: Tetranychidae). Experimental and Applied Acarology, Amsterdam, 23: 632-632.

Carey, J.R. \& J.W. Bradley. 1982. Developmental rates, vital schedules, sex ratios, and life tables for Tetranychus urticae, T. turkestani and T. pacificus (Acarina: Tetranychidae) on cotton. Acarologia, Montpellier, 23 (4): 333-345.

Cavalcante, R.D.; M.S. Melo \& J.L.N. Pinho. 1977. Ácaros tetraniquídeos atacando soja (Glycine max) no Estado do Ceará. Fitossanidade, Fortaleza, 3 (2): 41-42.
Crooker, A. 1985. Embryonic and juvenile development - The Tetranychidae, p.149-163. In: W. Helle \& M.W. SABELIS (Eds). Spider mites their biology, natural enemies and control. Amsterdam, Elsevier, 1A, 199p.

Flechtmann, C.H.W. 1989. Ácaros de importância agrícola. São Paulo, Nobel, 189p.

Flechtmann, C.H.W. \& J.M. Abreu. 1973. Ácaros fitófagos do Estado da Bahia, Brasil. Ciência e Cultura, São Paulo, 25 (3): 244-251.

Jeppson, L.R.; H.H. Keifer \& E.W. BaKer. 1975. Mites injurious to economic plants. London, University of California, 416p.

Moraes, G.J. DE \& C.H.W. Flechtmann. 1981. Ácaros fitófagos do Nordeste do Brasil. Pesquisa Agropecuária Brasileira, Brasília, 16 (2): 177-186.

Moraes, G.J. DE \& J.A. McMurtry. 1987. Effect of temperature and sperm supply on the reproductive potential of Tetranychus evansi (Acari: Tetranychidae). Experimental \& Applied Acarology, Amsterdam, 3: 95-107.

Moraes, G.J. DE; J.A. McMurtry \& E.W. BAKer. 1987. Redescription and distribution of the spider mites Tetranychus evansi and T. marianae. Acarologia, Montpellier, 26 (4): 333-343.

Noronha, A.C.S.; G.J. de Moraes \& A.I. Ciociola. 1995. Biologia de Mononychellus tananjoa (Bondar) (Acari: Tetranychidae) em variedades de mandioca. Anais da Sociedade Entomológica do Brasil, Londrina, 24 (3): 489-494.

Noronha, A.C.S.; M.A.C. BoaretTo \& A.E.L. Ribeiro. 2004. Ácaros em Maracujazeiro, p. 212-221. In: A.A. Lima \& M.A.P. CunHA (Eds). Maracujá: Produção e Qualidade na Passicultura. Cruz das Almas, Embrapa Mandioca e Fruticultura, 396p.

OchoA, R.; H. Agullar \& C. Vargas. 1994. Phytophagous mites of Central America: an illustraded guide. Turrialba, Catie, $234 \mathrm{p}$.

São José, A.R.; T.N.H. Rebouças; M. De M. Pires; D.N. Angel; I.V.B. Souza \& M.P. Bomfiм. 2000. Maracujá - práticas de cultivo e comercialização. Vitória da Conquista, UESB, 79p.

Received in 12.VII.2005; accepted in 27.IV.2006. 